\title{
A QUESTION OF FEDERAL CRIMINAL PROCEDURE
}

An interesting question which has not yet been determined by the Supreme Court of the United States, is whether the Federal statutes provide any means by which a corporation which has been indicted in one of the Federal districts, but is not found within that district, may be removed thereto for trial upon the indictment.

Under the penal provisions of the postal laws of the United States and of the Sherman Act and Interstate Commerce Act, and perhaps under other Federal criminal statutes, an indictment may be returned against a corporation in a district court of the United States in a district in which the corporation has neither an office, an agency nor property, and in which it is not engaged in the transaction of any business. Section 3894 of the Revised Statutes, which is the section prohibiting the use of the mails for lotteries, gift concerts or other similar enterprises, makes the offense one, either where the letter is mailed, or where it is delivered to the person to whom it is addressed and expressly enacts that the prosecution may be had in the district in which the publication was mailed, or to which it is carried by mail for delivery, or at which it is caused to be delivered by mail to the person to whom it is addressed.

In the Armour Packing Company case, 209 U. S., 56, the prosecution was based upon a charge that the Armour Packing Company had obtained transportation at less than the rates prescribed by the published tariffs, and had thereby violated the Act to Regulate Commerce. In that case it was contended that the alleged offense was complete in the State of Kansas, where the contract of carriage was made, and the transportation commenced, and that the prosecution could not be maintained in the western district of Missouri. - In support of this contention it was earnestly urged that in so far as the Interstate Commerce Act authorizes a prosecution outside of the district where the contract for the carriage is made and where the carriage commences, it is unconstitutional because of the requirement of the Sixth Amendment to the Constitution of the United States, that criminals be prosecuted and punished in the State or district where they are committed. The Supreme Court, sustaining Judge Smith Mc- 
Pherson who presided at the trial in the district court, in overruling this contention, held that the crime consisted in receiving the transportation at less than the tariff rates, and said:

"This is a single, continuing offense, not a series of offenses, although it is continuously committed in each district through which the transportation is received at the prohibited rate." The jurisdiction, so far as the constitutional requirement is concerned, depends upon "the locality of the offense, and not the personal presence of the offender."

Three concrete cases involving an effort to remove a corporation from one district to another for trial have arisen, all of them recently, one in the southern district of Iowa, and the others in the western district of Tennessee- one for an alleged violation of the postal laws, one for rebating in violation of the Interstate Commerce Act, and one for conspiracy under the Sherman Act. The Tennessee court held that it had the right to bring in the foreign corporation by a summons; the Iowa court reached the contrary conclusion. The question which it is proposed to consider is which of these conclusions is correct.

The jurisdiction of the district courts of the United States extends only to persons and things within their respective districts. This is a matter of purely statutory authority. It was at an early day recognized that the Congress has the power to authorize process of the district and circuit courts to run anywhere within the jurisdiction of the United States. The policy has been, however, to confine them rigidly to their respective districts and circuits, with some few exceptions, immaterial here, such as subpoenas, final process in favor of the United States, and process issued under the Sherman Anti-Trust Law. It is held in numerous cases, that in the absence of an express enactment by the Congress, the process of these courts cannot run outside their territorial jurisdiction.

An interesting case, showing the strictness with which this doctrine has been applied, is In re Anderson, 94 Fed., 487. A decree had been entered by a United States Court in Tennessee, with reference to certain lands lying on the border line between that State and North Carolina, jurisdiction of which had at one time been in dispute between the two States. Under a writ of possession issued under this decree, a deputy marshal inadvertently attempted to act while over the line in North Carolina, and was committed on a charge of assault and other trespasses in that State. The court refused him a writ of habeas corpus, holding 
that the marshal was protected by his process in Tennessee "but not one inch beyond such district."

Another deputy United States marshal was sentenced by a Mississippi court on a charge of carrying concealed weapons. He instituted a habeas corpus proceeding. ${ }^{1}$ The facts were that while temporarily in Mississippi, near the State line, the deputy learned where a person for whom he had a warrant could be found in Tennessee, on the other side of the boundary. He armed himself and prepared to start in pursuit. Before starting the deputy was arrested on the charge of carrying concealed weapons, but was allowed to proceed upon his errand. The deputy arrested the offender and subsequently returned to Mississippi, where he was arrested and fined for the offense of carrying concealed weapons. In holding that the deputy was not entitled to a writ of habeas corpus, Justice Lamar, before whom the case was tried, says that the deputy's contention

"overlooks the vital principle running through our laws (and which is in fact admitted by the relator in another form) that, subject to certain well-defined exceptions (not material to be stated here) the authority of the United States marshals and their deputies to act in an official capacity is confined to the respective districts for which they have been appointed. Revised Statutes, $787 .{ }^{2}$ In this case the relator was a deputy United States marshal for the western district of Tennessee, and the warrant which he had for the arrest of Bowers had been issued by a United States commissioner for that district. No part of his district extended into Mississippi. The warrant was effective only in the western district of Tennessee. ${ }^{3}$ Moreover, the official character of the relator could be recognized only in that district. Outside of that district, except in certain special cases not material in this consideration, he was simply a private citizen, and, as such, was amenable to the laws of the place where he chanced to be. He could not serve the warrant outside of his district if he could not do the main act connected with the service of the warrant without his district, neither could he perform, outside of his district, such incidental preliminary acts as are claimed in this case to have been done in the line of his duty, and therefore in pursuance of the law."

Omitting further reference to the authorities enforcing the general proposition that process of the district and circuit courts is limited in its force to their respective territorial jurisdictions,

1 Walker v. Lee, 47 Fed., 645.

2 Fletcher v. United Stätes, 45 Fed., 213.

- Talland v. Sprague, I2 Pet., 300; Ex parte Graham, 3 Wash, C. C., 456; 4 Wash., C. C., 211 ; Day v. Manufacturing Co., Blatchf., 628. 
the final inquiry is whether the Congress has by affirmative legislation created an exception to this general rule by granting to the several district courts the power to remove a corporation from one district to another for trial. The only Federal statute relating to this subject is the Act of 1789 as amended, which now appears as Section IOI4 of the Revised Statutes. This section is as follows:

"For any crime or offense against the United States, the offender may, by any justice or judge of the United States, or by any commissioner of a circuit court to take bail, or by any chancellor, judge of a supreme or superior court, chief or first judge of common pleas, mayor of a city, justice of the peace, or other magistrate, of any State where he may be found, and agreeably to the usual mode of process against offenders in such State, and at the expense of the United States, be arrested and imprisoned, or bailed, as the case may be, for trial before such court of the United States as by law has cognizance of the offense. Copies of the process shall be returned as speedily as may be into the clerk's office of such court, together with the recognizance of the witnesses for their appearance to testify in the case. And where any offender or witness is committed in any district other than that where the offense is to be tried, it shall be the duty of the judge of the district where such offender or witness is imprisoned, seasonably to issue, and of the marshal to execute, a warrant for his removal to the district where the trial is to be had."

The provision for the removal of an offender is contained in the last sentence of the section, which makes it the duty of the judge, where the offender is imprisoned, to issue a warrant for his removal to the district where the trial is to be had, and makes it the duty of the marshal to execute this warrant.

The terms of this section negative its application to corporations. Its provisions for arrest, imprisonment and bail, clearly can refer only to natural persons, and the requirements that the judge of the district "where such offender is imprisoned" shall issue, and the marshal shall execute, a warrant for his removal, are essentially inapplicable to an artificial person.

In the two cases in Tennessee, where the court asserted this power, it is conceded that it cannot be deduced from this section.

The following excerpt is taken from the earlier case:

"Section Ior4 of the Revised Statutes provides the method by which a natural person, who may be indicted in the United States court, may be brought from another district into the district

-United States $v$. Standard Oil Co., 154 Fed., 728, and United States v. Virginia-Carolina Chemical Company, et al., I63 Fed., 66. 
wherein he is indicted for trial. But this statute is not effective here. This defendant is a corporation. It cannot be taken into custody and required to execute bond for its appearance, nor on its refusal or failure to do so, be committed to jail. Indeed, it can only appear before the court through its agent or attorney.

"In Bishop's New Criminal Procedure, Section 950a, Par. 3 , it is said: 'A corporation is an intangible creature of the law, which cannot be seized and held, or imprisoned, or hung like a human being. Therefore the only method for obtaining the necessary control of it is by notice served on its proper officer and steps to force it to appear by attorney. For without an appearance there can be no sentence; judgment by default being unknown in criminal cases.'

"Since this defendant cannot be arrested and brought within the territorial jurisdiction of the court, as in the case of a natural person, of necessity it must be brought by summons, if the court obtains jurisdiction of it, unless it shall voluntarily appear."

The procedure adopted by the Tennessee court in its attempt to secure jurisdiction was the issuance of a summons directing the defendant to appear and answer the indictment. This summons was served on the defendant in Indiana, the defendant having no agency, business or property in Tennessee. The court predicated its authority to issue this summons upon Section 716 of the Revised Statutes of the United States, also a part of the Judiciary Act of 1789 , which is set out below:

"The Supreme Court, and the Circuit and District Courts shall have power to issue writs of scire facias. They shall also have power to issue all writs not specifically provided for by statute which may be necessary for the exercise of their respective jurisdictions, and agreeable to the usages and principles of law."

There are a number of considerations which seem to demonstrate that the conclusion of the court was unsound, and that there was no authority whatever for the issuance of such a summons:

(a) It was early decided and is settled doctrine that this section cannot be invoked to enlarge the jurisdiction of the court. Writs under it can be issued only in aid of a jurisdiction already acquired. There are a number of authorities sustaining this proposition. ${ }^{5}$

(b) The fact that the Congress has specifically legislated upon this particular matter of extradition in Section IOI4, precludes

5 McClurg v. Silliman, 6 Wheat., 600 ; Bath Courty v. Any, 13 Wall., 244; Kendall v. United States, I2 Pet., 524; McIntyre v. Wood, 7 Cranch, 504; In re Paquet, II 4 Fed., 437. 
resort to the general provisions of Section 716. Both of these sections were a part of the Act of 1789 . If it had been the purpose of the Congress to provide for the removal of corporations, as well as natural persons, it is inconceivable that it would have omitted all mention of this matter in the section devoted to this subject, or that it would have contented itself with the very general provision of Section 716. The affirmative legislation as to this subject in Section IoI4 defines what the Congress intended and negatives the contention that its purpose was to grant other powers not definitely expressed. To paraphrase the language of Chief Justice Marshal ${ }^{\circ}$ the affirmative description of the powers of the court with reference to the removal of a defendant from one district to another for trial, must be understood as prohibiting the exercise of other powers than those described.

(c) This doctrine would authorize process in civil cases throughout the United States. The language of Section 716 is not limited to criminal cases. As a matter of fact, the vast majority of the writs issued by virtue of its authority have been issued in civil suits. By the terms of the section, this power is granted to both circuit and district courts. If the argument that it operated to confer upon the district courts the power to issue a summons running to a state outside of the district is sound by a parity of reasoning, it conferred a like power upon the circuit courts.

The argument by which the Tennessee court reaches its conclusion is not persuasive. In the opinion, the court after asserting its jurisdiction over offenses against the United States, states that nothing remains except to obtain jurisdiction over the defendant. The opinion then proceeds:

"Since Congress has not specifically provided for the issuance of the writ, nor the method of bringing defendants before the court in this character of cases, and since it is necessary that such writ issue to enable this court to exercise its jurisdiction, and since the issuance of such writ is agreeable to the usages and principles of law, I think that the process in this case is authorized by Section 716 , Revised Statutes.

"It would seem, that if the conclusion reached is not correct, then the Standard Oil Company of Indiana can accept rebates or concessions from every railroad company in each State of the Union, except the State of Indiana, of which the defendant is a citizen, and defy the courts beyond that jurisdicition, on the

- United States v. More, 3 Cranch, 159. 
ground that no United States court outside the State of Indiana is authorized to issue process to the district of Indiana, and cause the same to be served upon the defendant, summoning it to appear before such court for trial. In other words, the Standard Oil Company of Indiana, would be beyond the jurisdiction of United States courts, except the United States courts for the district of Indiana, and therefore immune from punishment for violating the law for which it is indicted in this case, unless that punishment be imposed by a United States court for the district of Indiana."

This is an argument ex necessitate, pure and simple. It justifies the issuance of the writ upon the theory that it is necessary that the court have this power, not upon any act of the Congress granting this power. But what powers the Congress should have vested in the court was beside the issue. The question before the court for determination was whether the Congress had granted this power, not whether it ought to have made such a grant. If the Congress had erred, to quote from Justice Harlan in the Northern Securities case:

"The remedy for the error and the attendant mischief is the selection of new Senators and Representatives, who, by legislation, will make such changes in existing statutes, or adopt such new statutes, as may be demanded by their constitutents and be consistent with law."

The case in the southern district of Iowa is not reported. It arose subsequent to the Standard Oil Company case, and was a prosecution for an alleged violation of a postal statute. After an indictment had been found, an application was made for a summons requiring the defendant, a New Jersey corporation, to appear and plead to it. This application the court refused, declining to follow the Tennessee decisions, and holding that inasmuch as there is no statute authorizing such a procedure, the court was without jurisdiction to issue the writ.

The considerations to which reference has been made, seem to point conclusively to the correctness of this decision of the Iowa court. Section 716 does not confer upon the district courts of the United States, power to issue process directed against foreign corporations outside of their respective districts. It would seem to be obvious that the Congress omitted to provide for the extradition of corporations; this provision the courts may not supply, and without such provision there is no method by which a foreign corporation can be required to make an involuntary appearance to an indictment found outside the district in which it is located, or has an agency or business. 
It should not be inferred that the foregoing conclusion involves failure or even substantial embarrassment in the prosecution of offenders against the Federal laws. Danger of a miscarriage of justice may be averted by commencing the prosecution against the offending corporation in a district in which it has an agency, or in which its principal place of business is located.

The reason why, at the outset, no provision was made for the removal of corporations from one district to another is not far to seek. There was then no occasion for it, partly because of the relatively insignificant part which corporations then played in the business and commercial life of the country, and partly because at that time the occasion had not arisen for defining and punishing as crimes, many of the offenses to which reference has been made.

In closing, it may not be amiss to call attention to the significance of the fact that in the one hundred and twenty years which have elapsed since the enactment of the Judiciary Act of 1789 , there has developed no practical necessity for the removal of corporations from one judicial district to another for trial. Notwithstanding the notoriously bad repute in which corporations in general are held by certain classes, certainly not unimportant in their number, there could be no better demonstration that they have in general been law abiding, at least so far as the Federal statutes are concerned, than the fact that an experience of over a century had not resulted in the enactment of an extradition law applying to them. If experience had demonstrated the necessity for such a law it would have been promptly enacted.

Nathaniel T. Guernsey. 